\title{
Total Digestible Nutrient (TDN) Ransum Domba yang Mengandung Kulit Buah Melinjo
}

\author{
Total Digestible Nutrient (TDN) of Sheep Ration Containing Melinjo Fruit Peel
}

\section{F. S. F. Hasanah, R. Septiana, R. Ardiansyah, R. B. A. Eryanto, T. Dhalika, R. Hidayat, A. R. Tarmidi, dan I. Hernaman}

\author{
Fakultas Peternakan Universitas Padjadjaran \\ Jalan Raya Bandung - Sumedang KM 21 Sumedang 45363 \\ Corresponding Author: iman.hernaman@unpad.ac.id
}

\begin{abstract}
The melinjo fruit peel is the potential as an energy source for ruminant feed, but currently not many have used it. The aim of this study was to measure the total digestible nutrient (TDN) of the ration containing melinjo fruit peels. Twenty ewes were allocated to 5 types of treatment rations containing $0 \%(\mathrm{R} 1), 5 \%$ (R2), 10\% (R3), 15\%, and $20 \%$ (R4) melinjo fruit peel. The study was conducted using a completely randomized design, while the collected data were analyzed by using the Duncan test. The variables measured were the digestibility of crude protein, crude fat, crude fiber, nitrogen free extract (NFE), and TDN. The results showed that the treatment had a significant effect $(\mathrm{P}<0.05)$ on the digestibility of crude fat, NFE, and TDN, but not to the crude protein and crude fiber digestibility. Rations using $20 \%$ melinjo fruit peel (R5) produced the highest BETN digestibility $(\mathrm{P}<0.05)$ the same as the R3 and R4 treatments. Meanwhile, crude fat and TDN had the lowest value $(\mathrm{P}<0.05)$ among treatments, however the TDN value $(70,17 \%)$ was still in the range of sheep needs. The conclusion showed that $20 \%$ melinjo fruit peel could be used as feed in sheep rations and resulted in optimal TDN values.
\end{abstract}

Keywords : Gnetum gnemon L., ration, sheep, total digestible nutrient

\begin{abstract}
ABSTRAK
Kulit buah melinjo memiliki potensi sebagai pakan sumber energi untuk ruminansia, namun saat ini belum banyak yang memanfaatkannya. Penelitian bertujuan untuk mengukur total digestible nutrient (TDN) ransum yang mengandung kulit buah melinjo. Dua puluh ekor domba betina dialokasikan ke dalam 5 macam ransum perlakuan yang mengandung $0 \%(\mathrm{R} 1), 5 \%(\mathrm{R} 2), 10 \%(\mathrm{R} 3), 15 \%(\mathrm{R} 4)$, dan 20\% (R5) tepung kulit buah melinjo. Penelitian dilaksanakan menggunakan rancangan acak lengkap, data yang terkumpul dianalisis dengan uji Duncan. Peubah yang diukur adalah kecernaan protein kasar, kecernaan lemak kasar, kecernaan serat kasar, kecernaan bahan ekstrak tanpa nitrogen (BETN), dan TDN. Hasil menunjukkan bahwa perlakuan memberikan pengaruh yang nyata $(\mathrm{P}<0,05)$ terhadap kecernaan lemak kasar, kecernaan BETN dan TDN dan tidak terhadap kecernaan protein kasar dan kecernaan serat kasar. Ransum yang menggunakan kulit buah melinjo sebanyak 20\% (R5) menghasilkan kecernaan BETN yang paling tinggi $(\mathrm{P}<0,05)$ sama dengan perlakuan $\mathrm{R} 3$ dan $\mathrm{R} 4$. Sementara itu, lemak kasar dan TDN memiliki nilai yang paling rendah $(\mathrm{P}<0,05)$ diantara perlakuan, akan tetapi nilai TDN $(70,17 \%)$ tersebut masih dalam kisaran kebutuhan domba. Kesimpulan menunjukkan bahwa tepung kulit buah melinjo sebanyak $20 \%$ dapat dimanfaatkan sebagai bahan pakan dalam ransum domba dan menghasilkan nilai TDN yang optimal.
\end{abstract}

Kata kunci: domba, melinjo (Gnetum gnemon L.), ransum, total digestible nutrient

\section{PENDAHULUAN}

Pakan merupakan salah satu unsur yang sangat penting dalam menunjang kesehatan, pertumbuhan, dan reproduksi ternak. Pakan yang diberikan kepada ternak harus mengandung nutrien yang baik, karena pakan yang baik akan menjadikan ternak sanggup melaksanakan kegiatan serta fungsi proses dalam tubuh secara normal yang mampu meningkatkan produktivitas ternak tersebut. Pakan yang diberikan pada ternak haruslah tidak bersaing dengan kebutuhan manusia, harganya murah, dan mudah didapat.

Limbah pertanian memiliki potensi yang besar sebagai sumber bahan pakan alternatif, salah satunya adalah kulit buah melinjo (Gnetum gnemon L.). Kulit buah melinjo ini sudah dimanfaatkan sebagai sumber pangan untuk sayuran, namun jumlah pemanfaatannya terbatas sehingga kulit buah melinjo yang tidak termanfaatkan terbuang dan menjadi limbah di lokasi produksi. 
Kulit buah melinjo merupakan limbah yang berasal dari industri rumah tangga pembuatan emping melinjo. Pada musim panen, produksi melinjo dapat menghasilkan kulit buah melinjo segar sebesar $38,27 \%$ dari total produksi. Pada tahun 2014, produksi melinjo di Indonesia mencapai 197.647 ton per tahun (Direktorat Jenderal Hortikultura Kementrian Pertanian, 2015). Panen melinjo diperkirakan menghasilkan kulit buah melinjo segar sekitar 75.640 ton per tahun.

Hasil analisis menunjukkan bahwa kulit buah melinjo memiliki kandungan karbohidrat tinggi yaitu sebesar $76,33 \%$ dengan imbangan karbohidrat struktural dan non struktural adalah $23,05 \%$ dan $53,28 \%$ atau proporsinya mencapai 1 : 2,3. Limbah ini mengandung protein kasar sebesar $15,31 \%$, sehingga menjadikan kulit buah melinjo tergolong sebagai bahan pakan sumber energi (Hartadi et al., 2005). Karbohidrat non struktural yang terdapat pada kulit buah melinjo lebih besar daripada karbohidrat struktural, hal ini akan memudahkan mikroba rumen mencerna melalui proses fermentasi yang menghasilkan produk berupa asam lemak terbang dan dimanfaatkan sebagai sumber energi bagi mikroba rumen serta induk semangnya (Teti et al. 2018). Berdasarkan pengamatan di lapangan, kulit buah melinjo memiliki tekstur yang lembek dan mudah hancur, sehingga diharapkan mampu dicerna lebih baik dan memberikan sumbangan energi yang tinggi.

Di Indonesia, formulasi ransum ternak ruminansia menggunakan satuan energi yang masih didasarkan pada total digestible nutrient/TDN (Indah et al. 2020). Meskipun demikian, penggunaan satuan tersebut memiliki kelemahan, yaitu tidak memperhitungkan kehilangan zat-zat nutrien yang dibakar pada saat metabolisme dan energi panas yang timbul saat mengkonsumsi pakan (Ferrel dan Oltjen 2008). Untuk menghitung nilai TDN membutuhkan nilai kecernaan lainnya, yaitu kecernaan protein kasar, kecernaan lemak kasar, kecernaan serat kasar dan kecernaan bahan ekstrak tanpa nitrogen (BETN). Khusus untuk kecernaan lemak dalam menghitung TDN harus dikalikan dengan 2,25, karena memiliki energi lebih tinggi dibandingkan dengan senyawa nutrien yang lainnya (Hernaman et al. 2018).

Penelitian bertujuan untuk menghitung TDN ransum domba yang mengandung berbagai tingkat kulit buah melinjo.

\section{MATERI DAN METODE}

Penelitian menggunakan 20 ekor domba betina umur 11-12 bulan dengan bobot badan sebesar $22,7 \pm 1,38 \mathrm{~kg}$ dan koefesien variasinya $6,1 \%$. Domba tersebut dibagi ke dalam 5 perlakuan, masing-masing terdiri atas 4 ekor domba. Kandang yang digunakan merupakan kendang individu dengan sistem panggung. Ukuran kandang adalah $73 \times 125 \mathrm{~cm}^{2}$. Setiap kandang dilengkapi dengan tempat pakan dan minum, dan alat menampung feses dan urine.

Bahan pakan yang digunakan, yaitu kulit buah melinjo, dimana bahan pakan ini diperoleh dari Kabupaten Majalengka, Jawa Barat. Rumput lapangan diperoleh di sekitar kampus kawasan Jatinangor. Bahan pakan penyusun lainnya seperti bungkil kelapa, ampas kecap, dan onggok diperoleh dari KSU Tandangsari, sedangkan pollard diperoleh dari toko bahan pakan Missouri Bandung. Kulit buah melinjo sebelum dicampur dalam ransum dilakukan pengeringan dengan sinar matahari dan dilanjutkan oven $60^{\circ} \mathrm{C}$ sampai kering. Kemudian digiling sampai menjadi tepung dan dicampur dengan bahan pakan lain menjadi ransum komplit. Penelitian menggunakan 5 macam ransum perlakuan yang diberikan dalam bentuk ransum komplit. Ransum tersebut mengandung $0 \%, 5 \%, 10 \%, 15 \%$, dan $20 \%$ kulit buah melinjo. Susunan dan kandungan nutrien ransum perlakuan disajikan pada Tabel 1 .

Sebelum dilakukan koleksi data, terlebih dahulu domba diadaptasikan dengan ransum perlakuan selama 7 hari. Setelah itu dilakukan proses koleksi data dengan mengumpulkan data jumlah konsumsi ransum dan feses selama 10 hari. Pengumpulan sisa ransum dan feses mulai dilakukan pada pukul 07.00 WIB. Jumlah sisa ransum dikumpulkan, kemudian ditimbang. Seluruh feses yang terdapat dalam setiap kandang dikoleksi secara terpisah dengan kantong plastik yang berbeda untuk setiap harinya. Feses yang sudah terkumpul disemprot terlebih dahulu dengan asam borak $\left(\mathrm{H}_{3} \mathrm{BO}_{3}\right) 5 \%$ untuk mengikat nitrogen agar tidak terurai menjadi gas ammonia. Feses segar yang telah dikumpulkan secara terpisah, kemudian seluruhnya ditimbang dan diambil 10\%. Feses tersebut dijemur di bawah sinar matahari, dan ditimbang kembali setelah kering jemur. Semua feses dari setiap perlakuan diaduk sampai homogen. Sampel feses diambil $10 \%$ dari setiap perlakuan, untuk dianalisa kandungan nutriennya di laboratorium. 
Tabel 1. Susunan bahan pakan dan kandungan nutrien ransum perlakuan

\begin{tabular}{lccccc}
\hline Bahan Pakan & $\mathrm{R} 1$ & $\mathrm{R} 2$ & $\mathrm{R} 3$ & $\mathrm{R} 4$ & $\mathrm{R} 5$ \\
\hline Rumput Lapangan (\%) & 40,00 & 40,00 & 40,00 & 40,00 & 40,00 \\
Konsentrat: & 60,00 & 60,00 & 60,00 & 60,00 & 60,00 \\
Pollard (\%) & 24,83 & 20,90 & 16,03 & 11,50 & 7,18 \\
Onggok (\%) & 18,88 & 18,36 & 17,83 & 17,11 & 16,35 \\
Bungkil kelapa (\%) & 4,29 & 5,24 & 6,15 & 6,39 & 6,47 \\
Ampas kecap (\%) & 12,00 & 10,50 & 10,00 & 10,00 & 10,00 \\
Kulit buah melinjo (\%) & 0,00 & 5,00 & 10,00 & 15,00 & 20,00 \\
\hline Total & 100,00 & 100,00 & 100,00 & 100,00 & 100,00 \\
\hline Kandungan Zat Makanan & & & & & \\
\hline Bahan kering (\%) & 87,10 & 86,64 & 86,53 & 87,43 & 87,63 \\
Protein kasar (\%) & 13,95 & 15,33 & 13,9 & 14,72 & 14,06 \\
Lemak kasar (\%) & 12,58 & 12,63 & 10,44 & 12,33 & 8,88 \\
Serat kasar (\%) & 17,58 & 18,04 & 16,49 & 16,98 & 16,06 \\
Bahan ekstrak tanpa nitrogen (BETN) & 44,11 & 43,58 & 48,37 & 44,68 & 47,54 \\
Abu (\%) & 11,78 & 10,42 & 10,8 & 11,29 & 13,46 \\
\hline
\end{tabular}

Keterangan: Kandungan nutrien ransum perlakuan didasarkan pada perhitungan $100 \%$ bahan kering (BK)

Pengukuran Kecernaan Nutrien dan Total Digestible Nutrient

Kecernaan nutrien (protein kasar, lemak kasar, serat kasar, BETN) diperoleh dengan cara menghitung selisih konsumsi nutrien dalam ransum dikurangi dengan nutrien yang berada dalam feses. Pengukuran kandungan nutrien dalam ransum dan feses menggunakan metode analisis proksimat (AOAC, 1995). Total digestible nutrient diukur dengan menggunakan rumus sebagai berikut:

TDN $=\%$ PK DD $+\%$ SK DD $+\%$ BETN DD $+(2,25 \times \%$ LK $)$ Ket: $=$ DD (Dapat Dicerna) (Hernaman et al. 2018)

\section{Rancangan Percobaan}

Penelitian dilakukan secara eksperimental dengan menggunakan rancangan acak lengkap yang terdiri atas 5 perlakuan dan 4 ulangan. Data dihitung dan dianalisis dengan uji Duncan (Steel dan Torrie, 1995) menggunakan perangkat software SPSS 21.

\section{HASIL DAN PEMBAHASAN}

Hasil penelitian memberikan gambaran umum bahwa perlakuan menghasilkan pengaruh yang nyata $(\mathrm{P}<0,05)$ terhadap kecernaan lemak,
BETN dan TDN, namun tidak pengaruh nyata terhadap kecernaan protein kasar dan kecernaan serat kasar. Ransum yang menggunakan kulit buah melinjo sebesar 20\% (R5) menghasilkan kecernaan lemak kasar dan TDN yang paling rendah dibandingkan dengan perlakuan lainnya, sedangkan kecernaan BETN yang paling tinggi $(\mathrm{P}<0,05)$ dan hasilnya berpengaruh sama dengan perlakuan penggunaan kulit buah melinjo 10\% (R3) dan 15\%(R3).

Pencernaan pada hakekatnya adalah interaksi antara mikroba rumen dengan pakan dan ternak itu sendiri (Puastuti, 2009). Dalam proses pencernaan terjadi perubahan-perubahan bahan pakan baik secara fisik maupun kimia yang terjadi di dalam alat pencernaan serta dalam proses tersebut terdapat aktivitas penyerapan. Mengukur kecernaan protein kasar dilakukan untuk melihat sejauhmana protein itu diserap di dalam tubuh. Hasil penelitian menunjukkan bahwa kecernaan protein kasar pada ransum perlakuan sampai penggunaan kulit buah melinjo 20\% tidak memberikan pengaruh yang nyata. Hal ini disebabkan karena semua ransum perlakuan memiliki kandungan protein kasar yang relatif sama, yaitu pada kisaran 14,39-15\% (Tabel 1).

Tabel 2. Pengaruh perlakuan terhadap kecernaan nutrien

\begin{tabular}{|c|c|c|c|c|c|}
\hline Peubah & $\mathrm{R} 1$ & $\mathrm{R} 2$ & R3 & $\mathrm{R} 4$ & $\mathrm{R} 5$ \\
\hline Kecernaan protein $(\%)$ & $66,50 \pm 4,30$ & $68,35 \pm 2,34$ & $68,20 \pm 2,14$ & $70,67 \pm 4,71$ & $66,66 \pm 0,71$ \\
\hline Kecernaan lemak kasar (\%) & $87,39^{c} \pm 0,59$ & $87,59^{c} \pm 0,93$ & $85,94^{\mathrm{b}} \pm 1,20$ & $88,62^{c} \pm 0,75$ & $82,57^{\mathrm{a}} \pm 0,70$ \\
\hline Kecernaan serat kasar $(\%)$ & $62,44 \pm 2,75$ & $62,78 \pm 4,22$ & $62,51 \pm 3,82$ & $63,74 \pm 3,61$ & $61,65 \pm 1,47$ \\
\hline Kecernaan BETN (\%) & $70,15^{\mathrm{ab}} \pm 2,74$ & $67,09^{a} \pm 2,90$ & $74,24^{\mathrm{c}} \pm 1,48$ & $73,58^{\mathrm{bc}} \pm 2,45$ & $72,36^{\mathrm{bc}} \pm 2,47$ \\
\hline
\end{tabular}

Keterangan: Huruf yang sama ke arah baris menunjukkan pengaruh yang nyata $(\mathrm{P}<0,05)$ 
Dengan demikian mikroba rumen memperoleh pasokan protein asal pakan yang sama untuk digunakan dalam pertumbuhan terutama bakteri pencerna protein. Pertumbuhan bakteri proteolitik rumen yang relatif sama akan merombak atau memfermentasi protein yang sama, akibatnya memiliki nilai kecernaan protein yang sama.

Kecernaan lemak kasar untuk semua perlakuan rata-rata tinggi (di atas $80 \%$ ), hal ini karena struktur lemak lebih sederhana dibandingkan dengan senyawa nutrien yang lainnya (Wiseman, 1990), sehingga lebih mudah untuk dicerna. Hasil ini sama dengan penelitian Teti et al. (2018) yang menunjukkan kecernaan lemak kasar rata-rata di atas $80 \%$. Rataan kecernaan lemak tertinggi diperoleh pada perlakuan penggunaan kulit buah melinjo 15\% (R4), sedangkan ransum yang menggunakan kulit buah melinjo 20\% (R5) menghasilkan kecernaan lemak kasar yang paling rendah. Lebih rendah kecernaan lemak kasar pada perlakuan R5, karena ransum tersebut mengandung lemak yang paling tinggi, yaitu $5,51 \%$ (Tabel 1) diantara perlakuan lainnya. Tingginya lemak dalam ransum diduga memberi peluang lebih banyak lemak menempel dengan partikel pakan dan lolos dari saluran pencernaan, sehingga banyak yang terbuang atau tidak dicerna. Menurut Tanuwiria et al. (2011) bahwa lemak/minyak memiliki kemampuan berasosiasi dan menempel dengan partikel pakan, sehingga mengurangi kecernaan lemak.

Kecernaan serat kasar tidak menunjukkan adanya pengaruh diantara perlakuan. Seperti halnya pada kecernaan protein, hal ini karena kandungan serat kasar untuk semua ransum perlakuan relatif sama, sehingga bakteri rumen pencerna serat memiliki kesempatan yang sama dalam mencerna serat. Sementara itu, berbeda halnya dengan kecernaan BETN yang sama-sama dengan serat kasar sebagai karbohidrat menunjukkan adanya pengaruh nyata $(\mathrm{P}<0,05)$. Terdapat peningkatan kecernaan BETN pada ransum yang menggunakan kulit buah melinjo, dibandingkan dengan perlakuan kontrol/R1 (tanpa kulit buah melinjo), kecuali perlakuan R2 (penggunaan 5\% kulit buah melinjo) yang hasilnya relatif sama dengan perlakuan R1. Meskipun penggunaan kulit buah melinjo yang memberikan kontribusi rendahnya kandungan BETN dalam ransum (Tabel 1), namun ternyata dapat meningkatkan kecernaan BETN. Hal ini menunjukkan bahwa diduga BETN pada kulit buah melinjo lebih mudah untuk dicerna.
Kulit buah melinjo terindikasi secara kualitatif memiliki senyawa alami yang bersifat antinutrisi berupa tannin $(++)$ dan saponin $(+)$ (Dewi et al., 2012) dan kehadirannya menghambat aktivitas mikroba rumen dalam mencerna pakan (Makkar et al. 1995). Semakin banyak penggunaan kulit melinjo, maka semakin tinggi kandungan tannin dan saponin yang seharusnya berdampak pada kecernaan. Akan tetapi data yang diperoleh untuk penggunaan kulit melinjo yang paling tinggi, yaitu $20 \%$ tidak berpengaruh nyata terhadap kecernaan protein dan kecernaan serat kasar, kecuali untuk kecernaan lemak yang menghasilkan nilai yang paling rendah yang diduga karena tingginya lemak dalam ransum pada perlakuan tersebut. Bahkan di lain pihak penggunaan kulit buah melinjo yang tinggi justru dapat meningkatkan kecernaan BETN. Dengan demikian secara umum kehadiran senyawa tannin dan saponin dalam kulit buah melinjo tidak berpengaruh terhadap kecernaan. Hal ini bila dikaitkan dengan nilai TDN yang rendah (Gambar 1) pada perlakuan penggunaan kulit buah melinjo sebanyak $20 \%$, tampaknya diduga kuat juga bukan akibat dari kehadiran senyawa antinutrisi, namun hal ini karena kontribusi dari nilai kecernaan lemak yang rendah yang berdampak pada nilai TDN yang rendah. Kecernaan lemak kasar dalam perhitungan TDN akan dikalikan dengan 2,25 sehingga jika nilai kecernaan lemak kasar rendah, maka berakibat nilai TDN juga rendah. Kemungkinan tidak adanya pengaruh antinutrisi tersebut diduga disebabkan rendahnya konsentrasi senyawa antinutrisi dalam kulit melinjo sebagai akibat dari proses pengolahan berupa pengeringan dan penggilingan yang dilakukan sebelum digunakan sebagai bahan pakan. Menurut Yanuartono et al. (2019) bahwa proses pengolahan dengan pengeringan dan perubahan bentuk fisik menjadi lebih sederhana/digiling dapat mengurangi antinutrisi dalam pakan.

Meskipun penggunaan kulit buah melinjo 20\% (R\%) memiliki nilai TDN paling rendah, yaitu sebesar $70,17 \%$, namun nilai TDN tersebut masih dalam kisaran kebutuhan TDN untuk pertumbuhan domba betina yaitu sekitar $69,18 \%$ (Hernaman et al., 2018). Oleh karena itu, penggunaan tepung kulit buah melinjo sebanyak $20 \%$ masih layak diberikan dalam ransum domba dan akan lebih efisien digunakan sebagai bagian dalam ransum, jika kulit buah melinjo tersebut berupa limbah yang masih belum memiliki harga. 


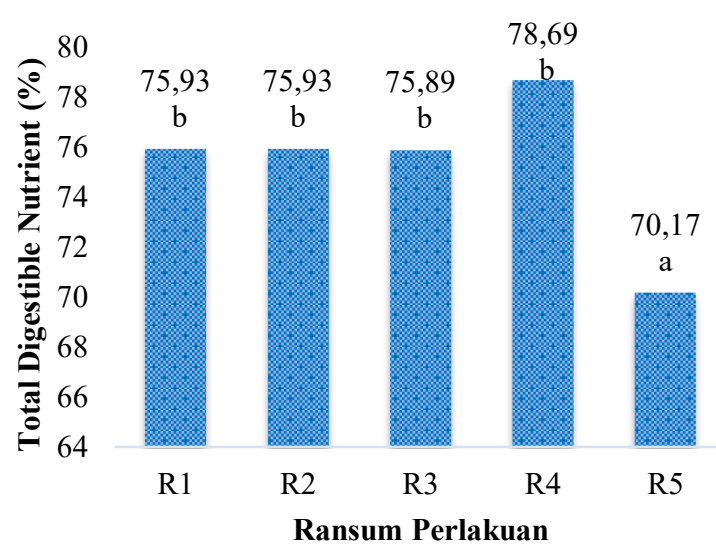

Gambar 1. Rataan total digestible nutrient ransum perlakuan

\section{KESIMPULAN}

Tepung kulit buah melinjo sebanyak 20\% dapat dimanfaatkan sebagai bahan pakan dalam ransum domba dan menghasilkan nilai TDN yang optimal.

\section{UCAPAN TERIMAKASIH}

Penelitian dilaksanakan di Peternakan milik PT. Agro Niaga Abadi serta untuk analisis proksimat dilakukan di Laboratorium Nutrisi Ternak Ruminansia dan Kimia Makanan Ternak Fakultas Peternakan Universitas Padjadjaran, Oleh karena itu, Kami mengucapkan banyak terimakasih kepada pengelola di kedua institusi tersebut atas fasilitas yang telah diberikan dalam pelaksanaan penelitian.

\section{DAFTAR PUSTAKA}

AOAC. 2005. Official methods of analysis of the Association of Analytical Chemist. Virginia USA: Association of Official Analytical Chemist, Inc.

Dewi, C., R. Utami, N.H. Riyadi P. 2012. Aktivitas antioksidan dan antimikroba ekstrak melinjo (Gnetum gnemon L.). Jurnal Teknologi Hasil Pertanian, 5 (2): $74-$ 81

Ferrel, C.L. and J.W. Oltjen. 2008. Asas centennial paper: net energy systems for beef cattle-concepts, aplication and future models. Journal of Animal Science 86:2779-2794.

Hartadi, H, Reksohadiprodjo, S, and Tillman, A. D. 2005. Indonesian Feed Composition
Tables. Gadjah Mada University Press, Yogyakarta

Hernaman, I., B. Ayuningsih dan D. Ramdani. 2018. Perbandingan model pendugaan total digestible nutrient (TDN) dan protein tercerna pada domba Garut betina. Majalah Ilmiah Peternakan 21(3): 110-113.

Hernaman, I. B. Ayuningsih, D. Ramdani, M. Maisarah, and Siswoyo. 2018. Performance of Female Garut Lambs Fed Diet in Different Ratio of Protein and Total Digestible Nutrients. Jurnal Veteriner 19 (4): 568-573

Indah, A.S., I. G. Permana, dan Despal. 2020. Model pendugaan total digestible nutrient (tdn) pada hijauan pakan tropis menggunakan komposisi nutrient. Sains Peternakan 18 (1): 38-43

Makkar, H.P.S., Blummel, M., Becker, K.,1995. In vitro effect on interaction between tannins and saponins and fate of tannins in rumen. J. Sci. Food. Agric. 69: 481-493.

Puastuti, W. 2009. Manipulasi bioproses dalam rumen untuk meningkatkan penggunaan pakan berserat. Wartazoa 19: 180-190

Steel, R.G.D. dan J.H. Torrie. 1995. Prinsip dan Prosedur Statistika: Suatu Pendekatan Biometrik. Penerjemah: Sumantri, B. Gramedia Pustaka Utama, Jakarta.

Tanuwiria, U. H., Budinuryanto, D. C., Darodjah, S., dan Putranto, W. S. 2011. Studi pembuatan kompleks mineral-minyak dan efek penggunaannya dalam ransum terhadap fermentabilitas dan kecernaan (in vitro). Jurnal Ilmu Ternak 10 (1): 32-38.

Teti, N., R. Latvia, I. Hernaman, B. Ayuningsih, D. Ramdani, dan Siswoyo. 2018. Pengaruh imbangan protein dan energi terhadap kecernaan nutrien ransum domba Garut betina. JITP. 6 (2):97-101.

Wiseman, J. 1990. Variability in the Nutritive Value of Fats for Ruminant. Butterworths. London.

Yanuartono, A. Nururrozi, S. Indarjulianto, H. Purnamaningsih, dan S. Raharjo. 2019. Metode tradisional pengolahan bahan pakan untuk menurunkan kandungan faktor antinutrisi: review singkat. Jurnal Ilmu Ternak 19(2) : 97-107. 